\title{
Woodchuck Hepatitis Virus
}

National Cancer Institute

\section{Source}

National Cancer Institute. Woodchuck Hepatitis Virus. NCI Thesaurus. Code C124253.

A species of double-stranded, retro-transcribing viruses in the genus Orthohepadnavirus that is naturally capable of infecting the woodchuck Marmota monax. 